\title{
IMAGENS E PALAVRAS PARA PENSAR A ESCOLA: APONTAMENTOS SOBRE A REFORMA DO ENSINO MÉDIO
}

\author{
IMÁGENES Y PALABRAS PARA PENSAR LA ESCUELA: APONTAMENTOS SOBRE \\ LA REFORMA DE LA EDUCACIÓN SECUNDÁRIA EN BRASIL
}

\author{
IMAGES AND WORDS TO THINK THE SCHOOL: NOTES ON THE SECONDARY \\ EDUCATION REFORM
}

Francione Oliveira CARVALHO ${ }^{1}$

\begin{abstract}
RESUMO: Este artigo debruça-se sobre o ensino da Arte no Ensino Médio tendo como análise central a Medida Provisória ${ }^{\circ}$ 746/2016 transformada na Lei ${ }^{\circ}$ 13.415/2017 que alterou a LDB no 9.394/1996. A alteração trouxe retrocessos históricos em relação a presença da arte no currículo escolar e lançou questões fundamentais e urgentes para o debate, tais como a flexibilização da educação atrelada ao mercado de trabalho e o enfraquecimento do Estado de bem-estar social. À contramão das conquistas históricas dos arte-educadores brasileiros em relação à presença da Arte na escola, a Reforma do Ensino Médio destituiu vozes, direitos, e ao desvalorizar o ensino da Arte abriu brechas para precarizar tanto o trabalho dos professores quanto as possibilidades de conhecimento que a arte promove na educação.
\end{abstract}

PALAVRAS-CHAVE: Ensino da arte. Reforma do ensino médio. Currículo.

RESUMEN: Este artículo debruza-si sobre la enseñanza del Arte en la Educación Secundaria em Brasil. Teniendo como análisis céntrico la Medida Provisional $n^{\circ}$ 746/2016 transformada en la Ley $n^{o}$ 13.415/2017 que alteró la LDB $n^{\circ}$ 9.394/1996. La alteración trajo retrocesos históricos en relación la presencia del arte en el currículo escolar y lanzó cuestiones fundamentales y urgentes para el debate, tales como la flexibilización de la educación atrapada al mercado de trabajo y la atenuación del Estado de bienestar social. Al contramano de las conquistas históricas de los arte-educadores brasileños en relación la presencia del Arte en la escuela, la Reforma de la Educación Secundária en Brasil destituyó voces, derechos y al desvalorizar la enseñanza del Arte abrió brechas para precarizar tanto el trabajo de los profesores cuanto las posibilidades de conocimiento que el arte promueve en la educación.

PALAVRAS CLAVE: Enseñanza del arte. Educación secundaria en Brasil. Currículo.

ABSTRACT: This article focuses on the teaching of art in High School, with the central aim of analyzing the Provisional Measure no. 746/2016 voted into Law no. 13.415/2017 which altered the LDB no. 9.394/1996. The amendment brought historic setbacks to presence of art within the school curriculum and thus raised fundamental and urgent issues for the debate, such as making education flexible and oriented to the labor market and the weakening of the welfare

${ }^{1}$ Universidade Federal de Juiz de Fora (UFJF), Juiz de Fora - MG - Brasil. Professor da Faculdade de Educação da Pós-Doutorado no departamento de História da Universidade de São Paulo. ORCID: <http://orcid.org/00000001-7511-5708>. E-mail: francioneoliveiracarvalho@gmail.com

RIAEE - Revista Ibero-Americana de Estudos em Educação, Araraquara, v. 14, n. 3, p. 973-985, jul./set., 2019. e-ISSN: $1982-5587$. 
state. In opposition to the historic achievements of art educators in relation to presence of art at school, the reform of secondary education silenced voices, removed rights and, by devaluing the teaching of art, opened up loopholes for making more precarious both the work of teachers and the possibilities of knowledge that art promotes in education.

KEYWORDS: Art teaching. Secondary education reform. Curriculum.

\section{Introdução}

No segundo semestre de 2016, a sociedade brasileira, tendo à frente educadores, estudantes e arte-educadores, iniciou contundente debate a respeito da Medida Provisória da Reforma do Ensino Médio. Sancionada como lei, no início de 2017, pelo Governo Federal, a MP alterou a carga horária, o currículo, a contratação de professores, a epistemologia, ao abrir brechas para a ideia de polivalência do ensino da arte, e promoveu a "flexibilização" do Ensino Médio. Aprovada em caráter de urgência e sem consulta pública, a Reforma do Ensino Médio nos desafia a refletir sobre muitas questões, entre elas: Qual Ensino Médio desejamos para nossos jovens? Este desejo corresponde ao desejado pelos estudantes? Enquanto educadores, arte-educadores ou estudantes, desejamos atuar em qual Ensino Médio? Qual a importância da arte no currículo do Ensino Médio? Para que serve a escola neste ciclo da Educação Básica?

Desejos são forças tensionais que nos conduzem a determinados fins que, se alcançados, nos proporcionam satisfação e alegria. Refletir sobre desejos é também articular deslocamentos, possibilidades e ações. Pois somos impulsionados e levados a agir a partir do que desejamos, ao mudar nossos focos desejantes deslocamos também nossa energia e alteramos a maneira de agirmos no espaço público. Enquanto formador de licenciados em Arte, convivo, cotidianamente, com inúmeros desejos vindos dos futuros professores: acolher e ser acolhido pelas escolas que atuarão; encontrar cenários favoráveis à atuação docente; estar preparados para lidar com os desafios das salas de aulas; ser capaz de promover encontros significativos com a arte; não reproduzir as aulas maçantes e sem significado que vivenciaram ao longo de seus percursos escolares, não se desencantar com a escolha de ser professor.

Encantada pela força que há no desejar, a artista Rivane Neuenschwander (2003) criou a instalação Eu desejo o seu desejo, tendo como inspiração a tradição das fitas coloridas vendidas na igreja Nosso Senhor do Bonfim, em Salvador. Nelas, os fiéis depositam seus desejos ao amarrá-las no pulso e esperar que se rompam naturalmente como sinal de que os desejos foram alcançados. Mas, na instalação da artista, os desejos já estão postos, cada visitante acolhe aquele que lhe convém e é convidado a levá-lo consigo. 
Imagem 1 - Rivane Neuenschwander, Eu desejo o seu desejo (2003), Instalação com serigrafia sobre fitas de tecido, dimensões variáveis

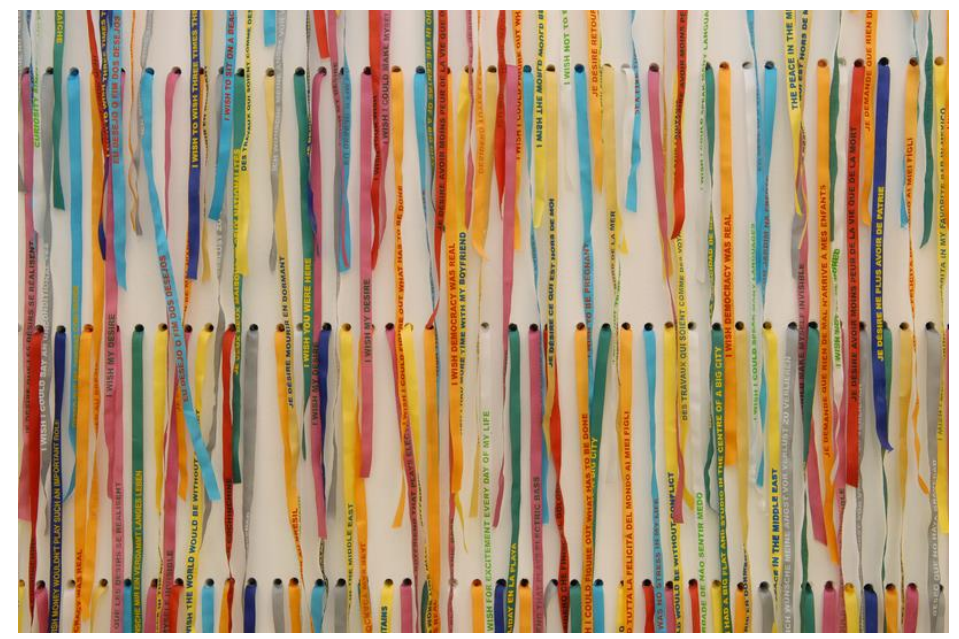

Fonte: Thyssen-Bornemisza Art Contemporaty, Áustria.

É possível desejar o desejo do outro. Mas este desejo terá forças para provocar os deslocamentos tão necessários à uma vida criativa e potente? Falando sobre experiência, Larrosa afirma que ela é "um saber particular, subjetivo; relativo, contingente, pessoal” (2002, p. 27), ou seja, possível de ser compartilhada, mas impossível de ser repetida. O mesmo poderíamos dizer sobre os desejos, por mais parecidos que eles possam ser, ninguém deseja do mesmo jeito, porque eles dialogam com subjetividades, anseios e histórias próprias e nos afetam de formas diferentes. Portanto, diferentes também devem ser as maneiras de alcançá-los. Pensando no exercício docente, poderíamos dizer que cada professor precisa reconhecer seus desejos e criar percursos próprios que só a experiência, compreendida tal como aponta Larrosa, pode ajudar a realizá-los e movê-los no eterno movimento de desejar.

A Reforma do Ensino Médio corresponde a quais desejos? Quem a deseja? É um desejo compartilhado por muitos? O que este desejo revela da educação? Da escola? Da arte? Se voltarmos à história da educação e das políticas públicas, veremos que quase sempre as mudanças educacionais são movidas por forças e interesses alheios aos que serão atingidos por elas. Por mais que a sociedade como um todo sinta os impactos das decisões e das escolhas políticas voltadas à educação, são os professores e alunos que sentem decisivamente seus efeitos. Entretanto, os desejos coletivos compartilhados por professores e alunos pouco são acolhidos por legisladores e, dessa forma, afetam as decisões políticas. Lugares de fala e de escuta silenciados que reforçam a falta de representatividade política. 
As reformas educacionais podem ser de longa ou curta duração, de grande ou pequeno impacto, de alta ou baixa qualidade, entretanto, revelam forças, desejos e tensões de uma época e de uma sociedade. Ao nos debruçarmos sobre o texto da Medida Provisória nº ${ }^{\circ}$ 746/2016 transformada na Lei $\mathrm{n}^{\circ}$. 13.415/2017, que alterou a LDB $\mathrm{n}^{\circ}$. 9.394, de 20 de dezembro de 1996, vemos retrocessos em desejos de educadores que pareciam já alcançados, como a valorização do ensino da Arte enquanto área de conhecimento própria e fundamental para a formação dos estudantes e a ênfase numa formação docente condizente com os desafios da educação na contemporaneidade.

Desde o final da década de 1970, o movimento arte-educação vinha na defesa e na construção de propostas que efetivassem a Arte no currículo escolar, desejo alcançado com a aprovação da LDB/1996. Esta revogou as disposições anteriores da Lei 5692/71, que havia instituído Educação Artística como atividade educativa que incluiria Artes Plásticas, Educação Musical, Artes Cênicas ministrada por um professor polivalente formado em cursos de curta duração.

Assim, ao afirmar que no currículo do Ensino Médio "incluirá obrigatoriamente estudos e práticas de educação física, arte, sociologia e filosofia" (Artigo $3, \S 2^{\circ}$ ), e "profissionais com notório saber reconhecido pelos respectivos sistemas de ensino, para ministrar conteúdos de áreas afins à sua formação ou experiência profissional [...]” (Artigo 6, IV), a Lei nº 13.415/2017 retrocede na caracterização da Arte enquanto componente curricular, pois "estudos e práticas" não garantem a autonomia enquanto área de conhecimento. Como também retrocede ao dar brechas para profissionais não licenciados atuarem no último ciclo da Educação Básica, minimizando a importância do saber docente e do saber ser professor de arte.

Na obra Sobre este mesmo mundo, de Cinthia Marcelle (2010), vemos o espaço de uma sala de aula vazia com vestígios de experiências vividas. A impermanência do fazer docente se mostra crua pois não há garantias do que será levado por cada um que esteve ali. A sobreposições de temas, conteúdos e anotações no quadro podem indicar perenidade de uma ação que se alimenta de repetições ou o reconhecimento da incerteza e da dúvida como motor do conhecimento vivo que exige infindáveis novos arranjos como os montes de giz no chão que se soprados pelo vento redesenhariam formas e linhas. Os mesmos montes brancos de giz podem nos remeter a uma experiência cristalizada, portanto uma não-experiência, já que quando vivida em plenitude a experiência não se esgota na ação. Ela ressoa e vive em nós. 
Imagem 2 - Cinthia Marcelle, Sobre este mesmo mundo (2010). Lousa e giz 120 x 840 $\mathrm{x} 8 \mathrm{~cm}$.

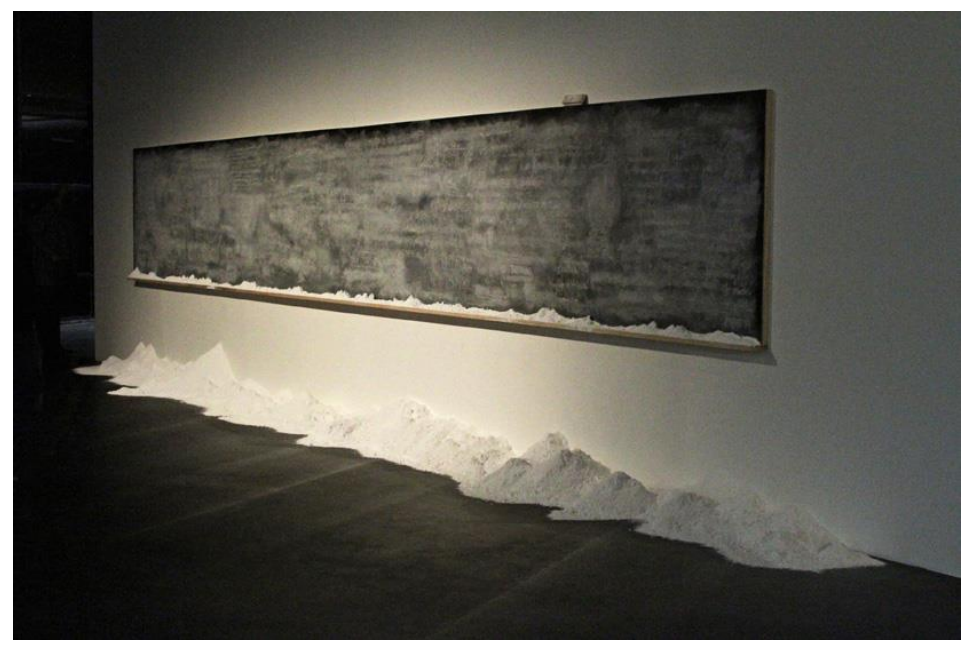

Fonte: Catálogo da $29^{\circ}$ Bienal de São Paulo (2010)

Lidar com a incerteza e as contradições vivenciadas numa sala de aula é uma articulação entre teoria e prática que revela uma práxis política inerente ao saber docente. É no curso de formação pedagógica e no tripé ensino/pesquisa/estágio que os futuros professores de Arte têm a oportunidade de pensar a educação tal como aponta Larrosa "a partir do par experiência/sentido" (2002, p. 20) Um processo de ensino e aprendizagem que dá significado "ao que somos e ao que nos acontece" (2002, p. 21). Falando sobre a necessidade de o ensino afrontar e comportar as incertezas Edgar Morin nos diz que é necessário "Aprender a navegar num oceano de incertezas através de arquipélagos de certezas" (2002, p. 19). Frase poderosa que nos lança num mundo de múltiplas possibilidades. Imagens e questões que nos conduzem ao universo da dúvida, dos questionamentos, afinal a educação e a arte deveriam ser pensadas a partir da transformação dos saberes e do enriquecimento das experiências num eterno devir, onde o acaso deve ser visto como possibilidade de criação e reinvenção. Num célebre poema Mallarmé escreveu "Um lance de dados jamais abolirá o acaso" (2014), mas se no lance tiver não um, mais dois dados, como na obra Desenhos do verso (2016) de Francis Alÿs, o imprevisto é potencializado?

Imagem 3 - Francis Alÿs, Desenhos do verso (2016). Da série In a Given Situation [Em uma dada situação], 2010-2016. Tinta, óleo e lápis sobre papel vegetal. 43 x 32,3 cm. 


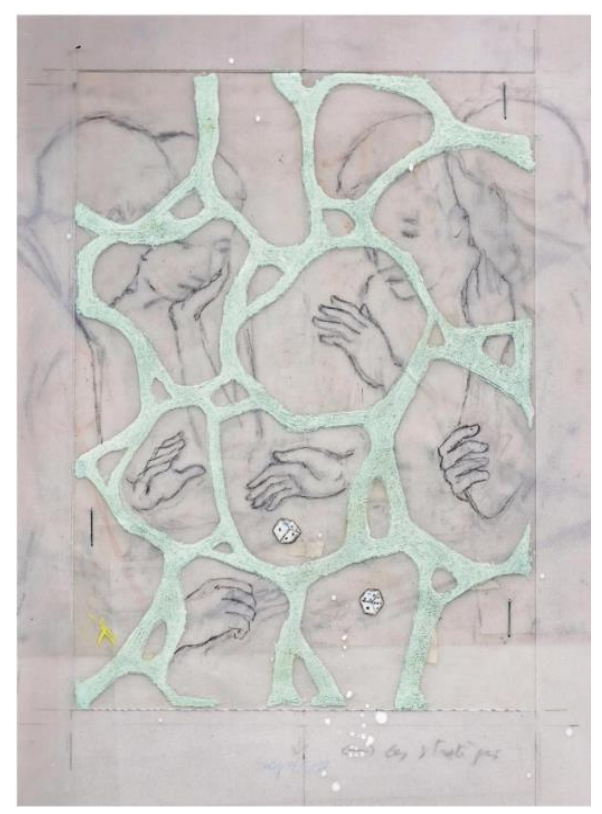

Fonte: Catálogo da $32^{\circ}$ Bienal de São Paulo (2016)

Por mais preparados que estejamos enquanto professores sempre estaremos lidando com o desconhecido, o inóspito, o diferente. Percorrendo caminhos novos e por que não perigosos? O perigo deve nos mobilizar e não nos paralisar, ser encarado positivamente tanto na arte quanto no ensino de Arte. Ele pode nos desafiar a percorrer trajetórias ainda não vividas e ser mobilizador para a criação docente.

Os personagens de Francis Alÿs parecem conectados e concentrados pela ação e alheios, ou até mesmo indiferentes, aos caminhos delineados à sua frente. Será que se interessam mais pelo resultado do lance no presente do que vislumbrar caminhos que os direcionem para o futuro e para o que está distante deles? Se pensarmos nas alterações da LDB/1996 a partir da Medida Provisória poderíamos dizer que elas revelam uma compreensão dos estudantes mais próximas da primeira impressão que a obra de Alÿs nos trouxe. Distantes das decisões, os estudantes não puderam participar da construção dos caminhos que a eles foram oferecidos. Existe escolha quando os dados são oferecidos, mas o resultado já está posto?

Art. $3^{\circ}$ A Lei $\mathrm{n}^{\circ}$ 9.394, de 20 de dezembro de 1996, passa a vigorar acrescida do seguinte art. 35-A:

Art. 35-A. A Base Nacional Comum Curricular definirá direitos e objetivos de aprendizagem do ensino médio, conforme diretrizes do Conselho Nacional de Educação, nas seguintes áreas do conhecimento:

I - linguagens e suas tecnologias;

II - matemática e suas tecnologias;

III - ciências da natureza e suas tecnologias;

IV - ciências humanas e sociais aplicadas (BRASIL, 2017). 
É interessante reconhecer que os estudantes poderão escolher a área de conhecimento a partir de seus interesses de aprofundamento, entretanto, do que adianta vislumbrar escolhas se na prática a lei não garante que as instituições ofereçam todos os trajetos? A elas cabe oferecer ao menos uma das áreas a partir de suas possibilidades materiais, estruturais e de pessoal, e aos alunos aceitar o que lhes é oferecido independente dos seus desejos.

Discorrendo sobre a Lei 5692/71 que instituiu a Educação Artística, Fusari; Ferraz (2001) já apontavam as contradições que permeiam as políticas públicas em relação ao ensino da arte. Pois para elas "a Educação Artística apresentava, na sua concepção, uma fundamentação de humanidade dentro de uma lei que resultou mais tecnicista" (Fusari; Ferraz, 2001, p. 20), além de apontarem que no Ensino Médio os paradoxos são ainda maiores pela proximidade de profissionalização e preparo para o mercado formal de trabalho.

O mesmo percebe-se em relação ao "Novo Ensino Médio". Na primeira versão da Medida Provisória, publicada em setembro de 2016, o componente curricular Arte deixava de ser obrigatório neste ciclo da Educação Básica. Decisão que provocou uma série de críticas em relação ao texto da proposta inicial. Alterada, a Arte retornou ao currículo, mas desconfigurada, como já apontamos anteriormente. Mas as contradições agudizam-se se voltarmos ao texto construído a partir de consulta pública da segunda versão da Base Nacional Comum Curricular, documento em debate no momento de criação da Medida Provisória 746/2016.

\footnotetext{
Artes Visuais, Dança, Música e Teatro devem estar presentes no Ensino Médio, assim como as propostas pedagógicas situadas nas fronteiras entre os componentes, integrando conhecimentos distintos, experiências de criação, com o objetivo de garantir o direito dos alunos ao exercício da autoria, do senso crítico e do trabalho coletivo que são próprios dos processos de criação artísticos. As artes podem incluir as práticas de cinema e audiovisual e o previsto na Lei 13006/2014.

Por isso, no Ensino Médio, Artes Visuais, Dança, Música e Teatro constituem os quatro componentes artísticos obrigatórios e devem ser ministrados cada um pelo respectivo professor, formado em uma das licenciaturas do campo artístico oferecidas no país: Artes Visuais, Dança, Música e Teatro (BRASIL, 2016, p. 517).
}

A BNCC aponta que seria preciso assegurar no Ensino Médio tempos, espaços e materiais adequados para o desenvolvimento de cada um dos quatro componentes. Importante lembrar ainda que em maio de 2016, portanto, antes da Medida Provisória, foi aprovada a Lei n. 13.278/16, que alterou a Lei das Diretrizes e Bases, incluindo as artes visuais, a dança, a música e o teatro no currículo do ensino fundamental. Se anteriormente os Parâmetros Curriculares Nacionais de Arte recomendavam que as escolas oferecessem as quatro linguagens, a nova lei promulgada as discriminou como obrigatórias no ensino da Arte. Mas, 
não distantes das contradições, a Lei n. 13.278/16 traz a obrigatoriedade das linguagens, mas não da formação especifica dos respectivos professores, abrindo brechas para o ressurgimento do combalido professor polivalente.

A ênfase tecnicista voltada ao trabalho apontada por Fusari; Ferraz (2001) a respeito da Lei n. 5692/71 retorna com força no "Novo Ensino Médio" a partir de duas questões: a ideia de que após a conclusão deste ciclo os estudantes estarão aptos a ingressar no mercado de trabalho, argumento central presente na maciça propaganda televisiva empreendida pelo Governo Federal na tentativa de convencer a população sobre a reforma educacional proposta, e a defesa do empreendedorismo.

A ligeireza na formação vinculada à empregabilidade são alguns dos motivos apontados por Masschelein; Simons (2015) que fazem com que muitas políticas educacionais reformulem os objetivos da educação em termos de competências para o mercado de trabalho. "O sucesso do termo "competências" - não somente no mundo profissional, mas também por toda a sociedade e educação - pode ser compreendido como um sintoma dessa ênfase na empregabilidade" (2015, p. 112). Além de reforçar tudo isso, o empreendedorismo tão alardeado e defendido pelo sistema financeiro faz com que os jovens acreditem que eles próprios são responsáveis pelo seu sucesso profissional e que isso não está atrelado a um sistema econômico perverso que não oferece as mesmas oportunidades a todos.

Na série Cartaz Ginasial (2008-2010), Gustavo Speridião explora imaginários juvenis associados à escola, tais como a falta de individualização dos estudantes, o descompasso entre o que ela propõe enquanto espaço de formação e os seus desejos e a ideia da escola como laboratório para o mundo produtivo do trabalho. Atrelar a educação ao trabalho e principalmente à empregabilidade parece um argumento poderoso numa época onde o desemprego alcança recordes nacionais. Sabemos que boas oportunidades escolares podem facilitar o acesso a profissões ou trabalhos qualificados, entretanto, também sabemos que isso não ocorre após a finalização do Ensino Médio. O que vemos é um cenário devastador, despreparados e esvaziados de cultura humanística mais ampla; a grande maioria dos estudantes acabam tornando-se empréstimos baratos para o capital. Dedicando grande parte da sua energia ao mercado de trabalho e na expectativa de "ascenderem" em suas empresas resta a estes jovens abreviar o máximo suas formações, incentivando o pernicioso mercado privado que "vende" graduação e pós-graduação ao mesmo tempo em dois anos. Sobre essa realidade, Mészáros afirma que o enfraquecimento da educação pública em contraponto ao fortalecimento do sistema privado "deu-se ao mesmo tempo em que a socialização se deslocou da escola para a mídia, a publicidade e o consumo" (2008, p. 16). 
Imagem 4 - Gustavo Speridião, Sem título, da série Cartaz Ginasial (2008 - 2010). Técnica mista e impressão serigráfica sobre papel, $95 \times 66 \mathrm{~cm}$.

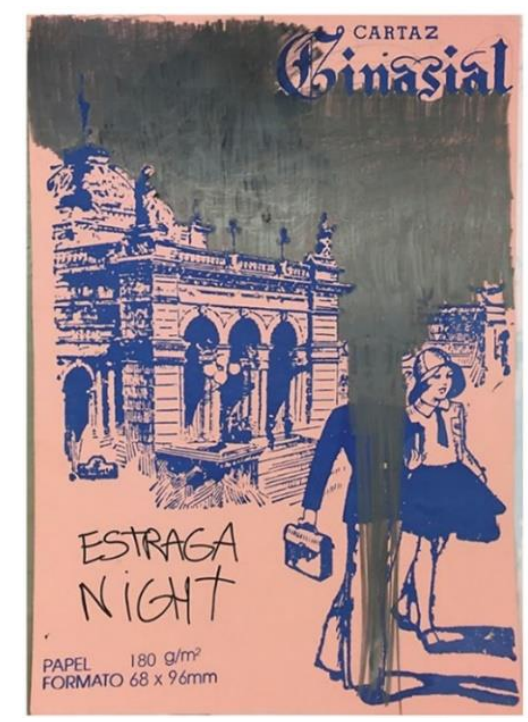

Fonte: Disponível em: http://www.premiopipa.com/pag/gustavo-speridiao/. Acesso em: 11 out. 2017

A Reforma do Ensino Médio está associada à discussão sobre a flexibilidade do mercado de trabalho e ao enfraquecimento do Estado de bem-estar social, reivindicação neoliberal que se fortalece, segundo Mészáros (2008), na década de 1980. E que hoje, pelas evidências cotidianas, se consolida na agenda política e econômica. Concordando com esta constatação, Standing (2013) nos alerta que a flexibilidade possui muitas dimensões: a flexibilidade salarial que tende a acelerar ajustes a partir da demanda do mercado; a flexibilidade de vínculo empregatício que reduz a segurança do trabalhador e os custos das empresas; a flexibilidade do emprego que possibilita às empresas modificar estruturas, custos e as funções dos trabalhadores sem alteração nos salários e a flexibilidade de habilidade, que segundo o autor seria a capacidade de ajustar as competências dos trabalhadores às necessidades do mercado. Desta forma, é imprescindível que enquanto educadores tenhamos clareza do que está verdadeiramente em pauta quando se fala de flexibilidade e de reforma estrutural no mundo do trabalho e de que maneira afirmamos ou nos insurgimos a partir de nossas práxis políticopedagógicas. Mészáros ainda nos alerta que a educação formal não é unicamente a força que consolida o sistema do capital e que ela por si só não fornece uma alternativa emancipadora radical. Para ele um dos objetivos centrais da educação formal na sociedade contemporânea "é produzir tanta conformidade ou "consenso" quanto for capaz, a partir de dentro e por meio dos seus próprios limites institucionalizados e legalmente sancionados” (Mészáros, 2008, p. 45). 
E a arte e a cultura como ficam neste cenário? "Com toda atenção focada na aquisição obrigatória e urgente de competências úteis, qualquer possibilidade de renovação e de tempo livre é suspensa" (MASSCHELEIN; SIMONS, 2015, p. 113). É importante situar que os autores resgatam a origem grega da palavra skholé como tempo livre para estudo e prática, valorizando com isso o processo de reflexão e de renovação do mundo.

Em suma, a tarefa da educação é garantir que o mundo fale com os jovens. Consequentemente, o tempo livre como tempo escolar não é um tempo para diversão ou relaxamento, mas é um tempo para prestar atenção ao mundo, para respeitar, para estar presente, para encontrar, para aprender e para descobrir (MASSCHELEIN; SIMONS, p. 98, 2015).

Se o tempo escolar é o tempo de prestar atenção ao mundo, as criações artísticas são importantes disparadores para percebermos como ele é visto, problematizado e recriado pelas pessoas. No texto $\mathrm{O}$ que pode a educação aprender das artes sobre a prática da educação? (2008), Elliot Eisner aponta que o aprendizado e a experiência que a arte traz para a educação não está restrita apenas a sua área de conhecimento, por isso, todos ganham com a sua presença nos currículos.

O autor elenca seis diferentes formas de pensar e articular pensamentos, formas e afetos característicos da arte que deveriam estar presentes em todos os aspectos que envolvem a escola e os processos educativos: 1. A composição, capacidade de compor relações qualitativas que satisfaçam algum proposito e que integrem sentimento e pensamento. Pensar na composição é investigar o que sustenta um argumento, um texto ou uma imagem. "Aprender a prestar atenção à maneira como a forma está configurada é um modo de pensamento que pode ser aplicado a todas as coisas feitas, sejam elas teóricas ou práticas" (EISNER, 2008, p. 10); 2. A flexibilidade de objetivos, a possibilidade de alterar os fins e os meios. Abertos à incerteza e à dúvida muitas vezes ao explorar ideias e materiais, os artistas seguem sugestões e intuições que os levam para caminhos não antes pensados e neste processo os objetivos são revistos. 3. A relação intrínseca entre forma e conteúdo, "a forma como uma coisa é dita é parte e parcela do que é dito" (EISNER, 2008, p. 11). 4. A pesquisa, os limites do conhecimento não podem ser delimitados pelos limites da linguagem. Dessa forma é fundamental a incessante busca de novas formas de expressar significados e ampliar saberes porque o significado não está limitado àquilo que pode ser decifrado. 5. A relação entre o pensamento e a materialidade, cada material impõe as suas exigências distintas e o artista precisa tanto conhecê-los quanto explorá-los para encontrar a forma perfeita às suas ideias. "Cada material novo oferece-nos novas restrições e despesas e, no processo, desenvolve os modos sobre os quais nós pensamos”. (EISNER, 2008, p. 14) 6. A 
motivação, os desejos e os interesses que estimulam o ato de criar. O que faz com que os artistas permaneçam numa ação mesmo ela muitas vezes os lançando em momentos de angústia e ansiedade? Além de satisfação estética é o desafio de superar limitações e ampliar suas experiências com o mundo e as pessoas. A resiliência e a vitalidade que marcam os processos de criação artística são aprendizados que podem ser cultivados além da arte.

\section{Considerações finais}

A arte está ancorada na experiência humana, que é múltipla e diversa, e compartilha uma forma sensível de perceber o mundo, portanto, é fundamental na escola. Algo parecido vemos na obra Lentes de contato (2011), da artista Haruka Kojin. Lentes de diferentes superfícies, formas e alturas que ajudam a ampliar a percepção e nos incentivam a romper com a monotonia de ver as coisas do mesmo jeito. Ver com novos olhos, rever aquilo que cotidianamente vemos, mas que anestesiados pelo cotidiano deixamos de perceber, é um desafio que temos como professores/mediadores de arte. Arnheim afirmou que "toda percepção é também pensamento, todo raciocínio é também intuição, toda observação é também invenção" (ARNHEIM, 2006, p. 1). Ninguém fica passivo ao entrar em contato com a arte. Ela mobiliza uma série de reflexões e inquietações, muitas vezes provocando em nós desconforto ao questionar nosso olhar sobre o mundo e nossa percepção sobre o que seria arte.

Imagem 5 - Haruka Kojin, Lentes de contato (2011). Instalação artística. Museu de Arte Contemporânea de Tóquio (MOT)

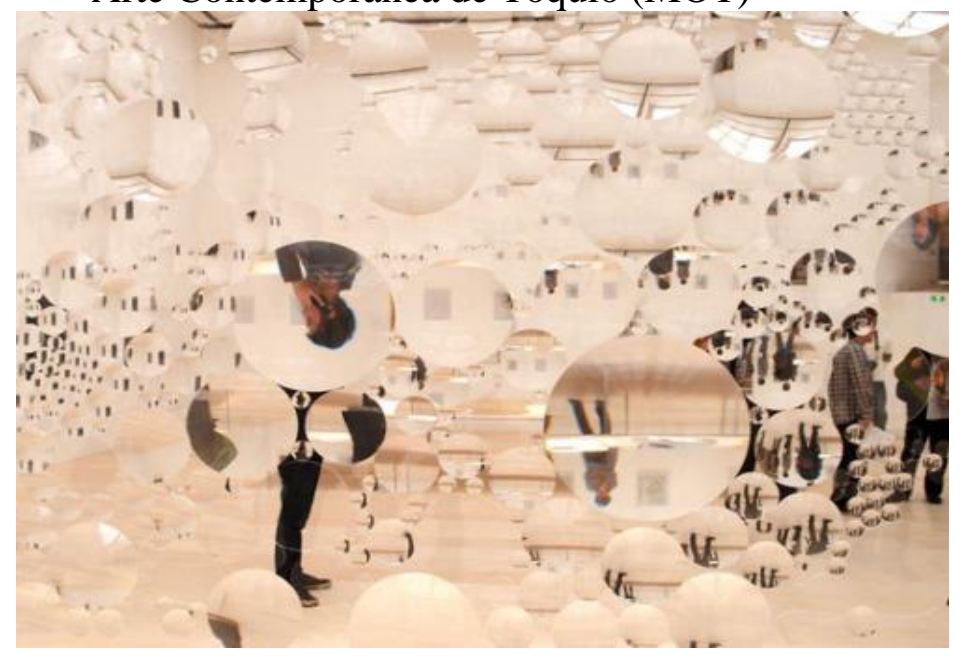

Fonte: Disponível em: http://dsign-magazine.com/art-contact-lens-by-haruka-kojin/. Acesso em: 11 out. 2017 
As criações artísticas nos revelam que há mais de uma maneira de perceber e sentir o mundo. Entre o que o artista criou e o que o público percebeu existe um universo de fatores que determinam a relação a ser estabelecida com a arte. Nossas histórias, experiências, gostos, repertórios e sentimentos influem decisivamente na maneira como percebemos a arte e somos tocados por ela. Portanto, o ato de aprender não é adaptar-se a um ambiente dado, uma simples adaptação conformista a uma realidade já existente, mas um processo de criação e intervenção do mundo. Desta forma, retirar ou minimizar a arte no currículo do Ensino Médio é privar os jovens de um conhecimento sensível fundamental para a renovação da vida.

\section{REFERÊNCIAS}

ARNHEIN, Rudolf. Arte \& Percepção Visual: uma psicologia da visão criadora. São Paulo: Thomson Learning, 2006.

BRASIL. Secretaria de Educação Fundamental. Parâmetros curriculares nacionais: Arte. Brasília: MEC/SEF, 1997.

BRASIL. Ministério da Educação. Base Nacional Comum Curricular. Proposta preliminar, segunda versão, revista. Abril, 2016. Disponível em:

http://basenacionalcomum.mec.gov.br/documentos/bncc-2versao.revista.pdf. Acesso em: 11 out. 2017

BRASIL. Lei $\mathbf{n}^{\mathbf{0}}$ 13.278, de 2 de maio de 2016. Altera o $\S 6^{\circ}$ do art. 26 da Lei $n^{\circ} 9.394$, de 20 de dezembro de 1996, que fixa as diretrizes e bases da educação nacional, referente ao ensino da arte. Disponível em: http://www.planalto.gov.br/ccivil_03/_ato2015-

2018/2016/lei/L13278.htm. Acesso em: 11 out. 2017.

BRASIL. Medida Provisória no 746, de 22 de setembro de 2016. Institui a Política de Fomento à Implementação de Escolas de Ensino Médio em Tempo Integral, altera a Lei $\mathrm{n}^{\circ}$ 9.394, de 20 de dezembro de 1996, que estabelece as diretrizes e bases da educação nacional e dá outras providências. Disponível em:

http://www.planalto.gov.br/ccivil_03/_ato2015-2018/2016/Mpv/mpv746.htm. Acesso em: 11 out. 2017.

BRASIL. Lei $\mathbf{n}^{\mathbf{0}} \mathbf{1 3 . 4 1 5}$ de 16 de fevereiro de 2017. Altera as Leis nos 9.394, de 20 de dezembro de 1996, que estabelece as diretrizes e bases da educação nacional, e 11.494, de 20 de junho 2007, que regulamenta o Fundo de Manutenção e Desenvolvimento da Educação Básica e de Valorização dos Profissionais da Educação, a Consolidação das Leis do Trabalho - CLT, aprovada pelo Decreto-Lei $n^{\circ} 5.452$, de $1^{\circ}$ de maio de 1943, e o Decreto-Lei $n^{\circ} 236$, de 28 de fevereiro de 1967; revoga a Lei $n^{\circ} 11.161$, de 5 de agosto de 2005; e institui a Política de Fomento à Implementação de Escolas de Ensino Médio em Tempo Integral. Disponível em:

http://legis.senado.leg.br/legislacao/ListaTextoIntegral.action?id=251273\&norma=270661. Acesso em: 11 out. 2017. 
EISNER, Elliot. O que pode a educação aprender das artes sobre prática da educação?

Currículo sem Fronteiras, v. 8, n. 2, pp. 5-17, jul./dez., 2008. ISSN 1645-1384.

FUSARI, Maria F. de Rezende e.; FERRAZ, Maria Heloísa C. de T. Arte na Educação

Escolar. São Paulo: Cortez, 2001.

LARROSA, J. Notas sobre a experiência e o saber da experiência. Revista Brasileira de Educação, Rio de Janeiro, n. 19, p. 20-28, jan./abr., 2002. ISSN 1413-2478

MALLARMÉ, Stéphane. Lance de Dados. Tradução: Álvaro Faleiros. São Paulo: Ateliê Editorial, 2014.

MASSCHLEIN, Jan; SIMONS, Maarten. Em defesa da escola: uma questão pública. Belo Horizonte: Autêntica Editora, 2015.

MÉSZÁROS, István. A educação para além do capital. São Paulo: Boitempo, 2008.

MORIN Edgar. Os sete saberes para a educação do futuro. Lisboa: Instituto Piaget, 2002.

STANDING, Guy. O precariado: a nova classe perigosa. Belo Horizonte: Autêntica Editora, 2013.

\section{Como citar este artigo:}

CARVALHO, Francione Oliveira. Imagens e palavras para pensar a escola: apontamentos sobre a reforma do Ensino Médio. Revista Ibero-Americana de Estudos em Educação, Araraquara, v. 14, n. 3, p. 973-985, jul./set., 2019. e-ISSN: 1982-5587. DOI: 10.21723/riaee.v14i3.10621

Data de Submissão: 06/11/2017

Revisões requeridas: 10/01/2018

Aceite em: 10/02/2018

Publicado em: 25/03/2018 